\title{
Pathologic/Prognostic Information
}

National Cancer Institute

\section{Source}

National Cancer Institute. Pathologic/Prognostic Information. NCI Thesaurus. Code C158859.

A header on a form about the pathologic/prognostic information. 